УДК 004.9: 378.046 .4

Ракута Валерій Михайлович

старший викладач кафедри інформаційно-комунікаційних технологій в освіті та методики їх використання

Чернігівський обласний інститут післядипломної педагогічної освіти імені К. Д. Ушинського, м. Чернігів, Україна

rakuta_valera@maill.ru

\title{
ДОСВІД ЗАПРОВАДЖЕННЯ СИСТЕМИ РОЗВИТКУ ПРОФЕСІЙНОЇ ІКТ-КОМПЕТЕНТНОСТІ ВЧИТЕЛІВ МАТЕМАТИКИ
}

\begin{abstract}
Анотація. Стаття присвячена аналізу проблем, що виникають у процесі підвищення рівня професійної майстерності вчителів математики у галузі використання інформаційнокомунікаційних технологій у навчальному процесі загальноосвітніх навчальних закладів i пошуку оптимальних шляхів їх розв'язання.

Розв'язати більшість проблем дозволить модернізація існуючої системи підготовки і підтримки професійного розвитку вчителів математики, яка полягатиме у розробці й упровадженні «Системи розвитку професійної ІКТ-компетентності вчителів математики», що забезпечуватиме перманентність міжкурсової підготовки вчителів і створюватиме оптимальні умови для реалізації індивідуальних траєкторій їх професійного розвитку.
\end{abstract}

Ключові слова: інформатизація; інформаційно-комунікаційні технології; математика; інновації; методика; навчальний процес; учителі математики; ІКТ-компетентність; використання IКТ; розвиток.

\section{1. ВСТУП}

Постановка проблеми. Рівень інформатизації нашого суспільства $є$ одним із визначальних факторів, що впливають на ступінь його розвитку й конкурентоспроможності. Недаремно на законодавчому рівні однією 3 основних стратегічних цілей розвитку інформаційного суспільства в Україні визначена така: забезпечення комп'ютерної й інформаційної грамотності населення, насамперед шляхом створення системи освіти, орієнтованої на використання новітніх IКТ у формуванні всебічно розвиненої особистості [3]. Її досягненню присвячена державна цільова програма впровадження у навчально-виховний процес загальноосвітніх навчальних закладів (ЗН3) інформаційно-комунікаційних технологій «Сто відсотків». Метою програми $\epsilon$ впровадження у навчально-виховний процес загальноосвітніх навчальних закладів інформаційно-комунікаційних технологій, створення умов для поетапного переходу до нового рівня освіти на основі зазначених технологій [2].

Повною мірою це стосується і такої навчальної дисципліни, як математика. На сучасному етапі розвитку шкільної математичної освіти однією з необхідних умов подальшого підвищення іiі рівня є запровадження в навчальний процес інформаційнокомунікаційних технологій і їх ефективне використання. Що, у свою чергу, залежить від того, наскільки володіє цими технологіями й уміє їх використовувати у своїй роботі кожен учитель математики. А це, значною мірою, визначається рівнем підготовки кожного фахівця [10]. Для того щоб така підготовка була максимально ефективною, потрібно розв’язати коло проблем, які обумовлені низкою протиріч, що мають місце в існуючих системах професійного розвитку вчителів математики у галузі використання інформаційно-комунікаційних технологій у навчальному процесі (НП) загальноосвітніх навчальних закладів (ЗНЗ). 
Аналіз останніх досліджень i публікацій. Проблемами, пов'язаними 3 інформатизацією шкільної освіти й підготовкою педагогічних працівників до використання IКТ у навчально-виховному процесі, займались такі науковці, як Жалдак М. І., Биков В. Ю., Морзе Н. В., Білоусова Л. І., Смирнова-Трибульска С. Н., Тришина С. В., Роберт І. В., Назаренко В. С., Акуленко В. Л. та інші.

Як ми зазначали раніше, «процес як підготовки майбутніх учителів, так і чергової курсової перепідготовки педагогічних кадрів, повинен розвиватися у двох напрямках. Перший - це підвищення якості й рівня загальної підготовки у галузі ІКТ, оскільки знання у цій галузі, зважаючи на темпи іiі розвитку, досить швидко застарівають, з'являються засоби з більшими можливостями, якісно нові, а, отже, набагато ефективніші. Зважаючи на це, навіть за умови отримання грунтовної підготовки у педагогічному університеті своєчасна, систематична й ефективна курсова перепідготовка $\epsilon$ необхідним елементом підвищення рівня фахової підготовки педагогічних працівників. Якщо ж ми будемо намагатись навчати педагогічних працівників, що не володіють на достатньому рівні засобами IКТ, їх використовувати, то цей процес, у кращому випадку, буде мало ефективним, а в гіршому — даремно витраченими коштами, часом і людськими ресурсами. Враховуючи темпи розвитку IКТ, така підготовка необхідна, має бути систематичною i проводитись під час проходження кожних чергових курсів підвищення кваліфікації не менше ніж один раз на п'ять років» [13].

Другий напрям - це підготовка вчителів до «використання IКТ у навчальновиховному процесі (НВП) з огляду на особливості кожного навчального предмета i професійні потреби педагогічних працівників різних спеціальностей» [13].

На нинішньому етапі розвитку вітчизняної освіти можна констатувати, що першому напряму приділяється значна увага. Як приклад можна назвати широко впроваджену в систему післядипломної освіти України програму корпорації Intel® «Навчання для майбутнього» (http://iteach.com.ua) і програми підготовки вчителів, які започатковані корпорацією Майкрософт «Курс цифрових технологій» і «Учителі в онлайні» (http://www.microsoft.com/ukraine/education/partnersinlearning/training-forteachers.mspx\#p2). Значну роль на даному етапі відіграли програми курсової перепідготовки, присвячені ліквідації комп'ютерної неграмотності педагогічних працівників і формуванню їх ІКТ-компетентностей.

Розглянемо тепер стан справ за другим напрямком. Програми розраховані на підготовку вчителів-предметників до використання ІКТ у навчально-виховному процесі (НВП) з огляду на специфіку кожного навчального предмета i професійні потреби педагогічних працівників різних спеціальностей або відсутні, або мають безсистемний характер. Позаяк, якщо говорити саме про підготовку вчителів математики, то у цій сфері $\epsilon$ значні здобутки й напрацювання, які мають інноваційний характер i відповідають сучасним міжнародним стандартам. Це праці таких вітчизняних дослідників, як Жалдака М. І., Горошка Ю. В., Ракова С. А., Семерікова С. О., Вінниченко Є. Ф., Гороха В. П., Покришня Д. А., Корольського В. В., Крамаренко Т. Г., Шокалюк С. В., Ракути В. М. та інших авторів.

У даному напряму $\epsilon$ і певні проблеми. «Переважна більшість робіт присвячена, головним чином, знайомству 3 функціональними можливостями таких програм, як Gran1W, Gran2D, Gran3D, DG, DERIVE, Advanced Grapher, та методикою їх використання для розв'язування різного типу математичних задач. Недостатня увага приділялася створенню науково-методичного та дидактичного забезпечення використання систем комп'ютерної математики (СКМ) для вивчення певних тем курсу шкільної математики, методиці створення та використання динамічних моделей у навчальному процесі (НП), застосуванню систем динамічної математики (СДМ) для 
розвитку дослідницьких та творчих здібностей учнів, організації модель-орієнтованого навчання. Впровадження існуючих розробок не набуло широкого розповсюдження та не стало системним. 3 різних причин використання СДМ, розроблених в інших країнах (GeoGebra, Cabri Geometry, Geometer's Sketchpad (GSP), «Живая математика», Kig, KSEG, GEONExT тощо), якщо і зустрічається, то $є$ фрагментарним та безсистемним. Фактично відсутнє відповідне науково-методичне та дидактичне забезпечення їх застосування у системі освіти України» [14]. Наприклад, однією з таких програм, які заслуговують на особливу увагу, є СДМ GeoGebra. Переважній більшості вчителів вона просто не відома.

Отже, у сфері підготовки вчителів математики до використання IКТ у НП існує комплекс проблем, які потребують аналізу й пошуку оптимальних шляхів їх розв'язання. Особливо це стосується підтримки розвитку професійної майстерності вчителів у період між курсами підвищення кваліфікації.

Мета статті. Аналіз і пошук шляхів ефективного розв'язання проблем, які виникають у процесі підготовки вчителів математики до використання інформаційнокомунікаційних технологій у навчальному процесі i ïx професійного розвитку в цій cфepi.

\section{2. МЕТОДИ ДОСЛІДЖЕННЯ}

Дослідження проводилось у рамках дослідно-експериментальної роботи з теми «Підготовка вчителів математики до використання інформаційно-комунікаційних технологій у навчальному процесі загальноосвітніх навчальних закладів». Під час дослідження використовувались такі методи:

- системний аналіз, порівняння й узагальнення філософської, психологопедагогічної, науково-методичної та навчальної літератури, інструктивнометодичної бази й інформаційних ресурсів, вивчення навчальних планів закладів післядипломної освіти, планів науково-методичної роботи районних методичних кабінетів, загальноосвітніх навчальних закладів 3 проблеми дослідження;

- аналіз функціональних можливостей сучасних IКТ на предмет їх використання у процесі вивчення шкільного курсу математики;

- вивчення й узагальнення вітчизняного і зарубіжного педагогічного досвіду у сфері навчання дорослих, систематизація та узагальнення власного педагогічного досвіду і досвіду колег;

- аналіз функціональних можливостей сучасних IКТ з точки зору можливості їх використання для створення оптимальних умов для розвитку професійної IКТкомпетентності вчителів математики ЗНЗ.

\section{3. РЕЗУЛЬТАТИ ДОСЛІДЖЕННЯ}

Спочатку розглянемо деякі поняття і терміни, які ми будемо використовувати нижче. Почнемо з поняття компетентності. Його аналізу приділяли увагу чимало науковців, серед них Овчарук О. В. Бобиєнко О. М. Хуторський А. В., Зимня І. А., Пометун О. І., Кодлюк Я. П. та інші. Єдина точка зору на трактування поняття «компетентність» зараз відсутня. Тому ми будемо використовувати тлумачення, яке найбільше відповідає розв' язанню наших завдань. 
Енциклопедія практичної психології подає таке трактування даного терміна: компетентність (від англ. competence) - сукупність компетенцій; наявність знань і досвіду, необхідних для ефективної діяльності в певній предметній галузі [4].

Як зазначено у [5], компетенція (від лат. competo - досягаю, відповідаю, підходжу) - стислий поведінковий опис того, що саме роблять люди для якісного виконання певної роботи (певного виду діяльності). Наприклад, компетенції «вміння доступно пояснювати складні поняття» або «навички використання наочності» $\epsilon$ індикаторами ефективності вчителя під час викладання нового матеріалу на уроці.

Компетенція - поведінковий стандарт ефективного виконання (тієї чи іншої) роботи (діяльності).

Компетенції можуть описувати як індивідуально-особистісні характеристики (наприклад, компетенція «стресостійкість», «схильність до командної роботи», «креативність» та ін.) [5], так і навички (наприклад, компетенція «вміння користуватися пошуковими системами для знаходження потрібної інформації в Інтернеті» або «використовувати електронну пошту»).

Відмінність компетентного фахівця від кваліфікованого в тому, що перший не тільки володіє певним рівнем знань, умінь, навичок, але і здатний реалізовувати їх у роботі. Компетентність передбачає наявність у людини внутрішньої мотивації до якісного здійснення своєї професійної діяльності, присутність професійних цінностей і ставлення до своєї професії як цінності. Компетентний фахівець здатний виходити за рамки предмета своєї професії, він володіє певним творчим потенціалом саморозвитку [5].

Отже, компетентність - це наявність знань, умінь, навичок, досвіду та інших особистісних якостей людини, необхідних для високоефективної діяльності в заданій предметній області.

Проблемами, пов'язаними 3 ІКТ-компетентністю вчителів, займались такі дослідники, як Жалдак М. І., Биков В. Ю., Безпалов П. В., Слізаров А. А., Морзе Н. В., Горошко Ю. В., Овчарук О. В., Смирнова-Трибульска О. Н., Шилова О. М., Лебєдєва М. Б., Спірін О. М., Горбунова Л. М. і Семибратов А. М., Литвинова С. Г., Насирова Н. В. та інші.

Науковці надають поняттю ІКТ-компетентності різні трактування.

- «П. В. Безпалов визначає дане поняття як інтегральну характеристику особи, що припускає мотивацію до засвоєння відповідних знань, здібність до вирішення завдань у навчальній і професійній діяльності за допомогою комп'ютерної техніки і володіння прийомами комп'ютерного мислення. Формується вона як на етапі вивчення комп'ютера, так і на етапі його застосування як засіб подальшого навчання та професійної діяльності і розглядається як одна з граней особової зрілості.

- А. А. Єлізаров під ІКТ-компетентністю розуміє сукупність знань, умінь і досвіду діяльності, причому саме наявність такого досвіду є визначальною стосовно виконання професійних функцій.

- О. М. Шилова та М. Б. Лєбєдєва визначають ІКТ-компетентність як здатність індивіда вирішувати навчальні, життєві, професійні задачі 3 використанням інформаційно-комунікаційних технологій.

- За Н. В. Насировою, це - мотивація, потреба й інтерес до отримання знань, умінь і навичок у галузі технічних, програмних засобів та інформації. Компетентність педагогів в галузі ІКТ розглядається Л. М. Горбуновою і А. М. Семибратовим як готовність і здатність педагога самостійно та відповідально використовувати ці технології у своїй професійній діяльності. 
- Українськими вченими також було розкрито зміст ключових компетентностей під час застосування інформаційних і комунікаційних технологій (О. В. Овчарук, М. І. Жалдак, Н. В. Морзе та ін.). Вони передбачають здатність орієнтуватися в інформаційному просторі, отримувати інформацію та оперувати нею відповідно до власних потреб і вимог сучасного високотехнологічного інформаційного суспільства» [18].

- О. М. Спірін вважає, що під інформаційно-комунікаційними компетентностями слід розуміти підтверджену здатність особистості застосовувати на практиці інформаційно-комунікаційні технології для задоволення власних потреб і розв'язування суспільно значущих, зокрема професійних, завдань у певній предметній галузі або виді діяльності [16].

Аналіз робіт науковців і рекомендацій ЮНЕСКО [17] щодо структури IКТкомпетентності вчителів показав, що у цьому питанні також існують різні підходи й точки зору.

У нашій роботі ми будемо використовувати такі трактування цього поняття і його структури:

ІКТ-компетентність - наявність знань, умінь, навичок, досвіду та інших особистісних якостей людини, необхідних для ефективного використання інформаційно-комунікаційних технологій у заданій предметній сфері.

Загальна ІКТ-компетентність - наявність знань, умінь, навичок, досвіду та інших особистісних якостей людини, необхідних для ефективного використання IКТ у своїй життєдіяльності (своєму житті).

Професійна ІКТ-компетентність учителя - наявність знань, умінь, навичок, досвіду та інших особистісних якостей людини, необхідних для ефективного використання IКТ у професійній діяльності педагога.

Профільна професійна ІКТ-компетентність учителя - наявність знань, умінь, навичок, досвіду та інших особистісних якостей людини, необхідних для ефективного використання IКT у професійній діяльності педагога, як учителя-предметника (наприклад, учителя математики).

3 огляду на наведені визначення загальну структуру ІКТ-компетентності вчителя можна подати у вигляді схеми (дивись рис. 1).

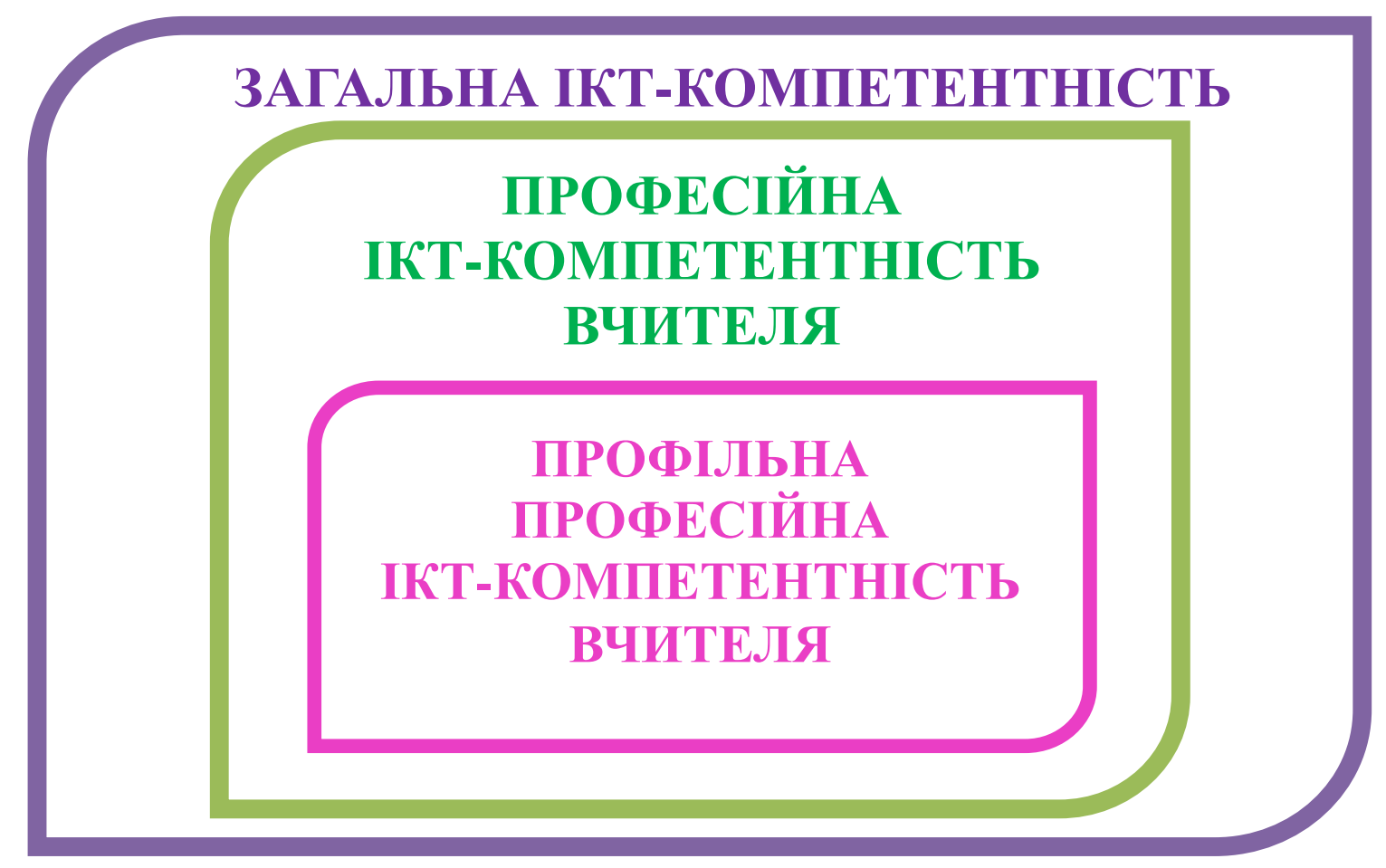


Як було зазначено вище, у сфері підготовки вчителів математики до використання IКТ у НП, існує комплекс проблем, які породжені певними протиріччями. Перша група протиріч має загальний характер і пов'язана зі світовими тенденціями розвитку людства, науки i технологій, результатами наукових досліджень, законодавством, що вимагають якнайширшого використання інформаційно-комунікаційних технологій у всіх галузях людського життя i, у першу чергу, у сфері освіти $[1 ; 2 ; 3 ; 18]$ і недостатньою підготовкою педагогічних працівників у галузі використання ІКТ у навчальновиховному процесі, зокрема це стосується і вчителів математики. Існуюча система підготовки вчителів математики частково розв'язує ці проблеми, але не завжди оптимально й повною мірою. Це пов'язано з низкою причин.

Однією 3 них є те, що значна частина вчителів не одержала в педагогічних навчальних закладах підготовки щодо використання IКТ у навчальному процесі, що зумовлює необхідність підвищення рівня їх професійної компетентності у цій галузі в системі післядипломної педагогічної освіти. 3 початком комп’ютеризації загальноосвітніх навчальних закладів (в Україні особливо активним цей процес став 3 початку XXI сторіччя і темпи його продовжують зростати) почала здійснюватись відповідна підготовка педагогічних працівників. У 2005 році на курсах підвищення кваліфікації при Чернігівському обласному інституті післядипломної педагогічної освіти імені К. Д. Ушинського було запроваджено модуль «Інформатика. Курс користувача для педагогічних працівників» (лекції - 10 годин, практичні - 10 годин), розроблений кандидатом (зараз доктором) педагогічних наук, завідувачем кафедри природничо-математичних дисциплін та інформаційних технологій Давиденко А. А. і старшим викладачем кафедри Ракутою В. М. 3 модулем можна познайомитися на сайті «Математика в школі онлайн» (https://sites.google.com/site/matematikaonlajn/ikt/ navcalni-programi-ta-plani).

Цей курс призначався в першу чергу для ліквідації комп'ютерної безграмотності педагогічних працівників. На момент його впровадження у більше ніж 75 відсотків учителів Чернігівської області елементарні навички роботи на комп'ютері були взагалі відсутні. Тому разом з програмою Intel® «Навчання для майбутнього» цей курс поклав початок формуванню професійної ІКТ-компетентності педагогів. Формування i розвиток профільної професійної ІКТ-компетентності вчителів математики досягались на цьому етапі за рахунок використання відповідного дидактичного забезпечення навчального процесу і приділення більшої уваги тим функціональним можливостям прикладних програм, які потрібні у процесі викладання саме математики. Як приклад можна навести роботу 3 редактором формул і векторним редактором текстового процесора Microsoft Word. Ïх можна використовувати для створення дидактичного забезпечення процесу вивчення математики у ЗНЗ (створення наочних посібників, виготовлення роздаткового матеріалу тощо). Також на цьому етапі з метою підвищення ефективності процесу підготовки педагогів під час курсової перепідготовки й активізації самостійної роботи вчителів, спрямованої на формування їх IKTкомпетентностей, були створені посібники $[10 ; 11 ; 12] .3$ ними також можна ознайомитись на сайті «Математика в школі онлайн» (https://sites.google.com/site/ matematikaonlajn/ikt/literatura-z-ikt).

У 2010 році модуль було оновлено й запроваджено курс «Інформаційні та телекомунікаційні технології у викладанні предмета (20 годин: 9 год. лекційні, 11 год. практичні)», розроблений Давиденко А. А., Ракутою В. М. та Літошем Ю. М. Зміст модуля можна переглянути на сайті «Математика в школі онлайн» (https://sites.google.com/site/matematikaonlajn/ikt/navcalni-programi-ta-plani). 
У зв'язку зі створенням в інституті кафедри ІКТ в освіті у 2011 році цей модуль було модернізовано. 3 діючими варіантами робочої навчальної програми і навчального плану також можна ознайомитися на вказаному вище сайті.

Усі розглянуті варіанти програм підготовки розраховані на різні категорії педагогічних працівників. Спеціалізація для вчителів математики на нинішньому етапі досягається за рахунок підбору змісту навчального матеріалу і відповідного дидактичного забезпечення.

Друга група протиріч пов'язана з темпами розвитку сучасних IКТ (у тому числі призначених для використання у процесі вивчення математики) й існуючою системою підвищення кваліфікації педагогічних працівників (1 раз на 5 років). Засоби IКТ стрімко розвиваються, виходять нові версії існуючих програм 3 новими функціональними можливостями, з'являються нові технології, дуже швидко відбувається розвиток сервісів Інтернету, особливо це стосується хмарних технологій. Тому система професійного розвитку вчителів математики у галузі використання IКТ у НП ЗНЗ (надалі вживатимемо скорочення - СПРВМІКТ) має відповідати вимогам сучасності.

Процес появи інновацій у галузі ІКТ має відслідковуватися й досліджуватися на предмет їх використання у НВП ЗНЗ із метою підвищення його ефективності. I у випадку позитивної відповіді СПРВМІКТ має забезпечувати оптимальні умови для їх упровадження у навчальний процес. Якісно це можна здійснити тільки за умови оперативного внесення змін як у систему професійного розвитку вчителів математики, так і у навчальний процес ЗНЗ. Отже, СПРВМІКТ має перманентно розвиватися й удосконалюватися паралельно з розвитком ІКТ. А це найкраще можна реалізувати за умови модульності її структури.

Як свідчать опитування й дослідження, проведені під час курсової перепідготовки, учителі математики мають різний рівень розвитку ІКТкомпетентностей. Різним $є$ також рівень забезпеченості комп'ютерною технікою i доступом до мережі Інтернет як навчальних закладів у цілому, так і кабінетів математики зокрема. У переважній більшості шкіл засоби ІКТ у кабінетах математики просто відсутні. Тому СПРВМІКТ має забезпечувати розв'язання (хоча б певною мірою) і цих проблем.

Потрібно взяти до уваги й те, що існуючі системи підвищення кваліфікації і професійного розвитку педагогічних працівників не завжди повною мірою (особливо це стосується сфери IКТ) використовують останні досягнення в психології і в галузі навчання дорослих. Це, насамперед, здобутки у галузі таких наук, як андрагогіка й акмеологія. Заслуговують на особливу увагу принципи особистісно-діяльнісного підходу [7], концепція пошукової активності [15] та методики коучингу [6; 8].

Ураховуючи зроблений аналіз, в основу модернізації СПРВМІКТ були покладені ідеї, подані нижче.

1. Створення сприятливих умов для розробки і реалізації вчителями математики індивідуальних траєкторій перманентного професійного розвитку в галузі використання IКТ у НП сприятиме підвищенню ефективності процесу їх професійного зростання.

2. Удосконалення існуючої програми курсової перепідготовки згідно з останніми досягненнями у сфері використання інформаційно-комунікаційних технологій у навчальному процесі, створення відповідного дидактичного і методичного забезпечення сприятиме підвищенню результативності навчального процесу на курсах підвищення кваліфікації.

3. Забезпечення перманентності професійного розвитку за допомогою введення системи міжкурсової підготовки створить оптимальні умови для реалізації 
індивідуальних траєкторій неперервного професійного розвитку вчителів математики, що полягатиме у запровадженні:

- експертів-координаторів у галузі використання IКТ у НП при кожному (або при групі з 2-3 шкіл) навчальному закладі і їх підготовці;

- дистанційних вузькопрофільних спецкурсів;

- системи сертифікації вчителів у галузі використання IКТ у процесі вивчення математики.

4. Використання останніх досягнень у психології і в галузі навчання дорослих у СПРВМІКТ дозволить підвищити її ефективність.

Реалізацією цих ідей стало створення «Системи розвитку професійної IКТкомпетентності вчителів математики». Ї̈і загальну структуру подано у вигляді схеми на рис. 2.

\section{СИСТЕМА РОЗВИТКУ ПРОФЕСІЙНОЇ ІКТ-КОМПЕТЕНТНОСТІ ВЧИТЕЛІВ МАТЕМАТИКИ}

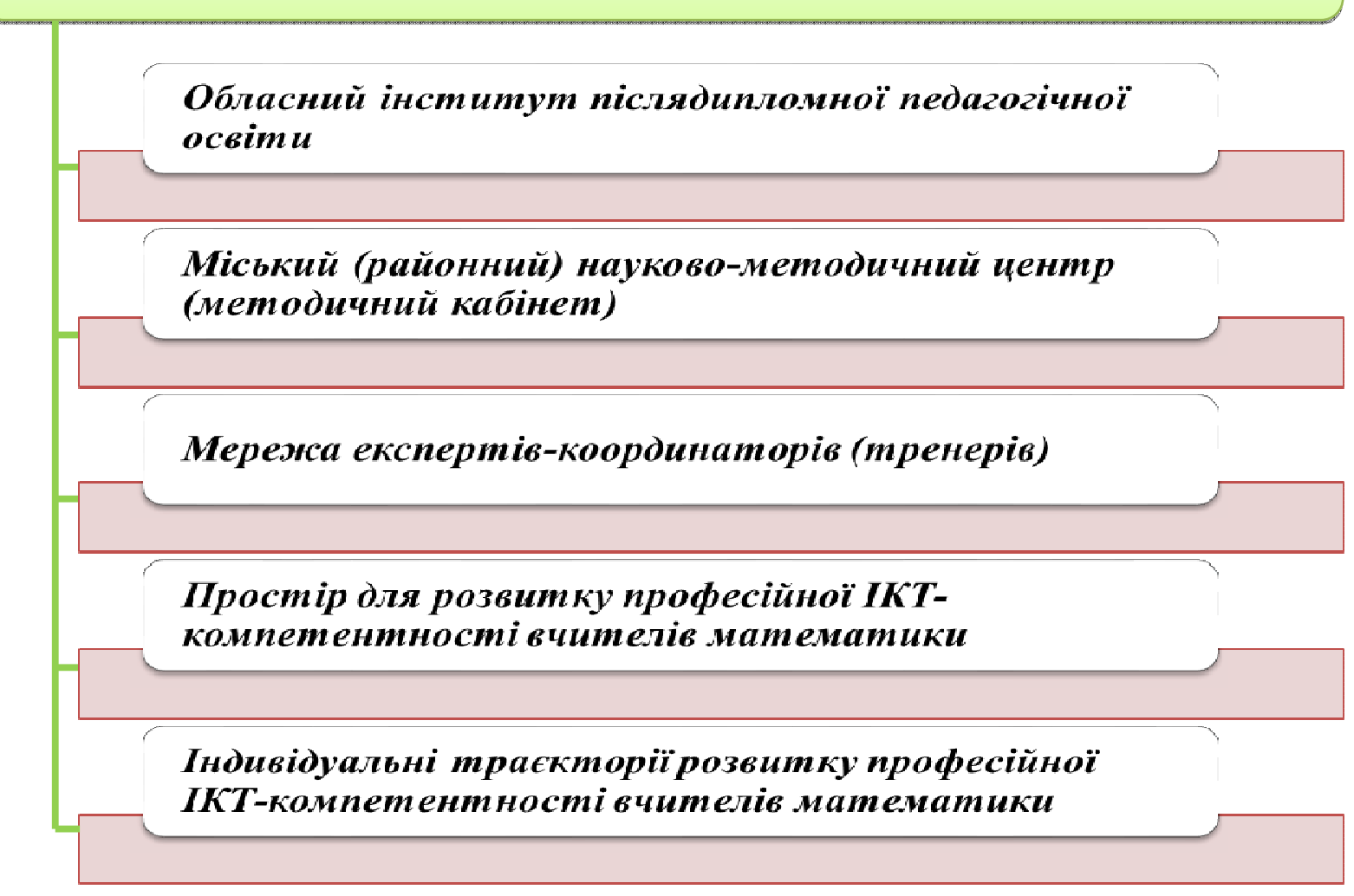

Рис. 2. Загальна структура системи розвитку професійної IКТ-компетентності вчителів математики

Розглянемо окремо кожний компонент.

Обласний інститут післядипломної педагогічної освіти (ОІППО), академія післядипломної педагогічної освіти або інший навчальний заклад, що відповідає за професійний розвиток педагогічних працівників області й займається організацією підвищення їх кваліфікації, виконує такі функції:

- організовує курсову перепідготовку вчителів і створює (разом із науковометодичними центрами, районними (міськими) методичними кабінетами) умови для підвищення рівня їх ІКТ-компетентності у міжкурсовий період; 
- разом із науково-методичними центрами, районними (міськими) методичними кабінетами здійснює моніторинг й аналіз рівня професійної ІКТ- компетентності педагогічних працівників;

- розробляє і підтримує «Простір для розвитку професійної ІКТ-компетентності вчителів математики»;

- організовує (разом з науково-методичними центрами, районними (міськими) методичними кабінетами) і здійснює підготовку експертів-координаторів;

- готує дидактичне забезпечення процесу розвитку професійної IКTкомпетентності вчителів математики як під час курсової перепідготовки, так і в період між курсами підвищення кваліфікації;

- розробляє положення про сертифікацію вчителів щодо рівня розвитку їх професійної ІКТ-компетентності і здійснює іï у співпраці 3 міськими (районними) науково-методичними центрами, районними (міськими) методичними кабінетами.

Міський (районний) науково-методичний центр (методичний кабінет) має такі функції:

- здійснює (разом з ОІППО) моніторинг і аналіз рівня розвитку професійної ІКТ компетентності педагогічних працівників;

- організовує (разом з ОІППО) підготовку експертів-координаторів;

- разом з ОІППО здійснює сертифікацію вчителів щодо рівня розвитку їх професійної ІКТ-компетентності;

- виконує контролюючі функції й надає допомогу експертам-координаторам в організації підготовки вчителів математики у галузі використання IКТ у навчально-виховному процесі ЗНЗ.

Мережа експертів-координаторів (тренерів) забезпечує:

- організацію підготовки вчителів у період між курсами підвищення кваліфікації, залучаючи, за потреби, викладачів з ОІППО;

- бере участь в організації досліджень й аналізі рівня професійної ІКТкомпетентності вчителів;

- допомагає вчителям у розробці й реалізації їх індивідуальних траєкторій розвитку професійної ІКТ-компетентності.

Простір для розвитку професійної ІКТ-компетентності вчителів математики визначає потенційні напрями й окреслює рамки підвищення рівня ІКТ-компетентності вчителів і відповідні вимоги до них. Він складається з трьох блоків.

1. Знання з ІКТ.

2. Уміння і навички використання IKT.

3. Творча майстерня професійного розвитку.

Кожний блок оцінюється певною кількістю балів (для позначення даної величини будемо використовувати термін —— «оцінка блоку», ОБ). Для блоків «Знання з IКТ» й «Вміння та навички використання ІКТ» ця кількість $€$ величиною сталою і дорівнює 100 балів (ОБ = 100) та 500 балів $($ ОБ = 500) відповідно.

У свою чергу блок складається з декількох тематичних модулів, а кожен модуль містить набір завдань і видів робіт. Кожне завдання (вид роботи) оцінюється певною кількістю балів, залежно від його складності. Складнішому завданню відповідає більша кількість балів.

Індивідуальні траєкторії розвитку професійної ІКТ-компетентності вчителів математики виконують такі функції:

- допомога вчителям у визначенні напрямів розвитку їх професійної IКТкомпетентності; 
- планування вчителями математики розвитку професійної ІКТ-компетентності на певний період (один або більше років);

- визначення вчителями математики рівня професійної ІКТ-компетентності, аналіз та оптимізація їі розвитку;

- визначення й аналіз рівня професійної ІКТ-компетентності вчителів математики під час курсової перепідготовки і створення на їх основі оптимальних умов для ії розвитку;

- визначення й аналіз рівня професійної ІКТ-компетентності вчителів математики районними (міськими) методичними службами і створення на цій основі (разом з ОІППО) оптимальних умов для іiі розвитку у період між курсами підвищення кваліфікації і здійснення сертифікації.

Більш докладну інформацію про систему розвитку професійної IKTкомпетентності вчителів математики і їі запровадження буде наведено в наших наступних публікаціях.

\section{3. ВИСНОВКИ ТА ПЕРСПЕКТИВИ ПОДАЛЬШИХ ДОСЛІДЖЕНЬ}

Проведений аналіз існуючих моделей підготовки вчителів математики до використання IКТ у НВП і професійного розвитку в цій галузі свідчить про їх недостатню ефективність і відповідність вимогам сучасності. У зв'язку з цим існує нагальна потреба у їх удосконаленні.

Результатом проведених досліджень стало створення і запровадження системи розвитку професійної ІКТ-компетентності вчителів математики, яка забезпечуватиме зростання рівня професійної ІКТ-компетентності педагогів і створить умови для перманентного розвитку педагогів у галузі використання інформаційно-комунікаційних технологій у навчально-виховному процесі загальноосвітніх навчальних закладів.

Потребують подальших досліджень, розробки та вдосконалення окремі елементи системи (наприклад, дидактичне забезпечення процесу розвитку професійної IКТкомпетентності вчителів математики, зокрема створення системи веб-ресурсів, присвячених підготовці вчителів математики до використання IКТ у навчальному процесі ЗНЗ).

Необхідно вдосконалити існуючі програми курсової перепідготовки вчителів математики згідно з останніми досягненнями у сфері використання інформаційнокомунікаційних технологій у навчальному процесі, створити відповідне дидактичне i методичне забезпечення.

Варто продовжити дослідження функціональних можливостей i розробку відповідних методик використання у навчальному процесі ЗНЗ України сучасних закордонних інноваційних програмних продуктів, призначених для використання у процесі вивчення математики (оскільки вони перманентно розвиваються й удосконалюються, наприклад, як це відбувається із системою динамічної математики GeoGebra).

\section{СПИСОК ВИКОРИСТАНИХ ДЖЕРЕЛ}

1. Горошко Ю. В. Інформаційне моделювання у підготовці учителів математики та інформатики : навчально-методичний посібник для студентів / Ю. В. Горошко. — Чернігів : Видавець Лозовий В. М., 2012. - 368 с.

2. Державна цільова програма впровадження у навчально-виховний процес загальноосвітніх навчальних закладів інформаційно-комунікаційних технологій "Сто відсотків" на період до 2015 року [Електронний ресурс]. — Режим доступу : http://zakon1.rada.gov.ua/laws/show/494-2011-п. 
3. Закон України «Про основні засади розвитку інформаційного суспільства в Україні на 2007-2015 роки» [Електронний ресурс] // Відомості Верховної Ради України (ВВР). — 2007. — № 12. - С. 102. — Режим доступу : http://zakon1.rada.gov.ua/laws/show/537-16. — Назва з екрана.

4. Компетентность [Електронний ресурс] // Психологос. Энциклопедия практической психологии. Режим доступу : http://www.psychologos.ru/articles/view/kompetentnost.

5. Компетенция [Електронний ресурс] // Психологос. Энциклопедия практической психологии. Режим доступу : http://www.psychologos.ru/articles/view/kompetenciya.

6. Коучинг [Електронний ресурс] // Вікіпедія. Вільна енциклопедія. - Режим доступу : http://uk.wikipedia.org/wiki/Коучинг.

7. Личностно-деятельный подход [Електронний ресурс] // Психологос. Энциклопедия практической психологии. - Режим доступу : http://www.psychologos.ru/articles/view/lichnostno-deyatelnyy _podhod.

8. Методика коучинга [Електронний ресурс] // Психологос. Энциклопедия практической психологии. — Режим доступу : http://www.psychologos.ru/articles/view/metodika_kouchinga.

9. Поисковая активность [Електронний ресурс] // Психологос. Энциклопедия практической психологии. - Режим доступу : http://www.psychologos.ru/articles/view/poiskovaya_aktivnost.

10. Ракута В. М. Використання IКТ при вивченні математики (Практикум. Частина I) : навчальний посібник. / В. М. Ракута. — Чернігів : ЧОІППО, 2008. - 46 с.

11. Ракута В. М. Основи інформаційних технологій (Інформаційна система. Основи роботи з ОС Windows. Графічний редактор. Текстовий редактор) : навчальний посібник. / В. М. Ракута. Чернігів : ЧОІППО, 2005. - $51 \mathrm{c.}$

12. Ракута В. М. Практичні завдання 3 основ ІКТ (Інформаційна система. Основи роботи 3 ОС Windows. Графічний редактор. Текстовий редактор) : навчальний посібник. / В. М. Ракута. Чернігів : ЧОІППО, 2007. - 43 с.

13. Ракута В. М. Проблеми інформатизації шкільної освіти / В. М. Ракута // Комп'ютер у школі та сім’ї. - 2008. - № 4. - C. 3-6.

14. Ракута В. М. Система динамічної математики GeoGebra як інноваційний засіб для вивчення математики [Електронний ресурс] / В. М. Ракута // Інформаційні технології і засоби навчання. 2012. — №4 (30). — Режим доступу до журналу : http://www.journal.iitta.gov.ua.

15. Ротенберг В. С. Мозг. Обучение. Здоровье : кн. для учителя / В. С. Ротенберг, С. М. Бондаренко. — М. : Просвещение, 1989. — 239 с.: ил. — (Психол. наука — школе).

16. Спірін О. М. Теоретичні та методичні основи кредитно-модульної системи навчання майбутніх учителів інформатики : дис. ... доктора пед. наук : 13.00.04 / Спірін Олег Михайлович. — К., 2009. $-495 \mathrm{c}$.

17. Структура ИКТ-компетентностей учителей. Рекомендации ЮНЕСКО. - Редакция 2.0. [Електронний ресурс]. — Режим доступу : http://iite.unesco.org/pics/publications/ru/files/3214694.pdf.

18. Формування та розвиток ІКТ-компетентності педагогів [Електронний ресурс] // ЗапоВики «wiki.ciit.zp.ua». — Режим доступу : http://wiki.ciit.zp.ua/index.php/Формування_та_розвиток_IКТкомпетентності_педагогів.

Матеріал надійшов до редакиї 05.10.2013 p.

\title{
ОПЫТ ВНЕДРЕНИЯ СИСТЕМЫ РАЗВИТИЯ ПРОФЕССИОНАЛЬНОЙ ИКТ-КОМПЕТЕНТНОСТИ УЧИТЕЛЕЙ МАТЕМАТИКИ
}

\author{
Ракута Валерий Михайлович \\ старший преподаватель кафедры информационно-коммуникационных технологий в образовании и \\ методики их использования \\ Черниговский областной институт последипломного педагогического образования имени \\ К. Д. Ушинского, г. Чернигов, Украина \\ rakuta_valera@maill.ru
}

Аннотация. Статья посвящена анализу проблем, возникающих в процессе повышения уровня профессионального мастерства учителей математики в области использования информационно-коммуникационных технологий в учебном процессе общеобразовательных учебных заведений и поиска оптимальных путей их решения.

Решить большинство проблем позволит модернизация существующей системы подготовки и поддержки профессионального развития учителей математики, которая будет заключаться 
в разработке и внедрении «Системы развития профессиональной ИКТ-компетентности учителей математики», которая будет обеспечивать перманентность межкурсовой подготовки учителей и создавать оптимальные условия для реализации индивидуальных траекторий их профессионального развития.

Ключевые слова: информатизация; информационно-коммуникационные технологии; математика; инновации; методика; учебный процесс; учителя математики; ИКТкомпетентность; использование ИКТ; развитие.

\title{
EXPERIENCE ON IMPLEMENTATION OF ICT COMPETENCE PROFESSIONAL DEVELOPMENT OF MATHEMATICS TEACHERS
}

\author{
Valerii M. Rakuta \\ senior lecturer, Chair of Information and Communication Technologies in Education and Teaching methods \\ Chernihiv Regional Institute of Post Diploma Pedagogical Education named after K. D. Ushynskyi, Chernihiv, \\ Ukraine \\ rakuta_valera@maill.ru
}

\begin{abstract}
The article is aimed to studying the points connected with upgrading Mathematics teachers in the field of using information and communication technologies in teaching process in secondary schools and finding ways out to solve the problems.

Modernization of the existing system of upgrading and supporting Mathematics teachers in their professional development can help to solve the problem. Its essence lies in working out and introducing the "System of ICT-Competence professional development of Mathematics teachers"” which provides the permanence of teachers' training and makes optimal terms for realization of individual trajectories of their professional improvement.
\end{abstract}

Keywords: informatization; information and communication technologies; Mathematics; innovation; methods; teaching process; studying; Mathematics teachers; ICT-Competence; ICT appliance; improvement.

\section{REFERENCES (TRANSLATED AND TRANSLITERATED)}

1. Horoshko U. V. Information modeling in training Mathematics and Informatics teachers: Teaching-methodic guide for students/ U. V. Horoshko. - Chernihiv : Publisher Lozovyi V.M., 2012. - 368 p. (in Ukrainian)

2. State special program of introduction of information and communication technologies into teaching and upbringing process in secondary schools "One hundred percents" up to 2015 [online]. — Available from : http://zakon1.rada.gov.ua/laws/show/494-2011-п. (in Ukrainian)

3. The law of Ukraine "On basic improvement grounds of information society in Ukraine for 20072015" [online] // Vidomosti of Verhovna Rada. - 2007. — № 12. — P. 102. — Available from : http://zakon1.rada.gov.ua/laws/show/537-16. (in Ukrainian)

4. Competence [online] // Psyhologos. Encyclopaedia on practical psychology [online]. - Available from : http://www.psychologos.ru/articles/view/kompetentnost. (in Russian)

5. Competence [online] // Psyhologos. Encyclopaedia on practical psychology. - Available from : http://www. psychologos.ru/articles/view/kompetenciya. (in Russian)

6. Couching. [online] / Wikipedia. Free Encyclopaedia. - Available from: http://uk.wikipedia.org/wiki/Коучинг. (in Russian)

7. Personal-active approach [online] // Psyhologos. Encyclopaedia on practical psychology. Available from : http://www.psychologos.ru/articles/view/lichnostno-deyatelnyy_podhod. (in Russian)

8. Couching methods [online] // Psyhologos. Encyclopaedia on practical psychology. - Available from : http://www.psychologos.ru/articles/view/metodika_kouchinga. (in Russian)

9. Searching activity [online]. - Available from: http://www.psychologos.ru/articles/view/poiskovaya_aktivnost. (in Russian)

10. Rakuta V. M. The use of ICT in studying Mathematics (Practice guide. Part I) : Training guide / V. M. Rakuta. - Chernihiv : COIPPO, 2008. - 46 p. (in Ukrainian) 
11. Rakuta V. M. The basics of informational technologies (Informational system. Basics of operating the OC Windows. Graphical editor. Text editor): Training guide / V. M. Rakuta. - Chernihiv : COIPPO, 2005. - 51 p. (in Ukrainian)

12. Rakuta V. M. Practical tasks on the basics of ICT (Informational system. Basics of operating the OC Windows. Graphical editor. Text editor): Training guide / V. M. Rakuta. - Chernihiv : COIPPO, 2007. - 43 p. (in Ukrainian)

13. Rakuta V. M. The problem of informatization of school education / V. M. Rakuta // Computer at school and at home. - 2008. - №4. - P. 3-6. (in Ukrainian)

14. Rakuta V. M. GeoGebra mathematics dynamic system as an innovative means for studying mathematics [online] / V. M. Rakuta // Informative technologies and teaching means. — 2012. № 4(30). — Available from : http://www.journal.iitta.gov.ua. (in Ukrainian)

15. Rotenberg V. C. Brain. Teaching. Health. Man. for a teacher. / V. C. Rotenberg, S. M. Bondarenko - M. : Prosweshchenie, 1989. — 239 p. — s il. — (Psychol. nauka — to school). (in Russian)

16. Spirin O. M. Theoretical and methodical base of credit-module system of training future Informatics teachers : Dis... d-r ped.sciences 13.00.04 / O. M. Spirin. - K., 2009. - 495 p.

17. Structure of ICT competence of teachers. Recommendations of UNICEF. - Editorial 2.0. [online]. — Available from : http://iite.unesco.org/pics/publications/ru/files/3214694.pdf. (in Russian)

18. Formation and improvement of ICT competence of teachers. [online] / Zapo.Viki "wiki.ciit.zp". Available from: http://wiki.ciit.zp.ua/index.php (in Ukrainian) 